\title{
С.А. Левицька
}

\section{КОРЕЛЯЦІЯ КЛІНІЧНИХ СИМПТОМІВ І РЕЗУЛЬТАТІВ КОМП'ЮТЕРНОӤ ТОМОГРАФІЇ ПРИНОСОВИХ СИНУСІВ У ХВОРИХ ІЗ РИНОЛОГІЧНОЮ ПАТОЛОГІСЮ}

Вищий державний навчальний заклад України «Буковинський державний медичний університет», м. Чернівці

Резюме. Визначена кореляція між інтенсивністю клінічних симптомів і результатами комп'ютерної томографії приносових пазух у 32 хворих на хронічний гіпертрофічний риніт, 28 хворих на хронічний ексудативний синусит, 24 хворих на хронічний поліпозний синусит і 20 осіб контрольної групи. Затемнення верхньощелепної пазухи виявлено в кожного четвертого обстеженого контрольної групи. Не виявлено кореляції

Вступ. Першим етапом діагностики в пацієнта хронічного синуситу (ХC) $є$ аналіз клінічних симптомів, який проводиться зазвичай лікарями загальної практики [5]. На другому і третьому етапах надання спеціалізованої медичної допомоги для визначення характеру і розповсюдженості запального процесу, вибору оптимальної тактики лікування хворого на ХС у перелік додаткових методів обстеження зазвичай включають комп'ютерну томографію (КТ) приносових пазух (ПНП) [2].

Водночас у науковій періодиці трапляються непоодинокі повідомлення про випадково виявлені рентгенологічні ознаки ХС при проведенні КТ ПНП у пацієнтів із відсутністю будь-яких клінічних симптомів захворювань верхніх дихальних шляхів $[4,6]$.

Зіставлення інтенсивності клінічних проявів i рентгенологічних ознак ХC дозволить визначити діагностичну цінність КТ ПНП і запобігти проведенню зайвих оперативних втручань.

Мета дослідження. Визначити кореляцію клінічних симптомів і результати КТ ПНП у хворих із різними формами ринологічної патології.

Матеріал і методи. КТ ПНП проведена 104 пацієнтам, розподілених на чотири групи. Першу групу склали 32 особи з хронічним гіпертрофічним ринітом (ХГР), другу - 28 хворих на хронічний ексудативний синусит (ХЕС); третю - 24 хворих на хронічний поліпозний синусит (ХПС); четверту (контрольну) групу склали 20 осіб із відсутністю анамнестичних вказівок на частий між рентгенологічними змінами за шкалою LundMackay та інтенсивністю головного болю. Встановлена кореляція середньої сили між інтенсивністю головного болю та інфільтративним вмістом верхньощелепної пазухи на комп'ютерній томограмі у хворих на ексудативний $(\mathrm{Sp}=0,32)$ і поліпозний синусити $(\mathrm{Sp}=0,32)$.

Ключові слова: комп'ютерна томографія, синусити, кореляція.

головний біль, обтяжений ринологічний анамнез, утруднене носове дихання.

Стан ПНП оцінювали за шкалою LundMackay [3]. Відчуття утруднення носового дихання визначали за аналоговою візуальною шкалою. Інтенсивність головного болю оцінювали за НІТ6 індексом [7].

Статистичну обробку отриманих результатів виконували методами варіаційної статистики за допомогою програми «Statistica 6» із використанням непараметричного критерію Mann-Whitney. Для визначення сили та направленості зв'язку між показниками проведений регресійний аналіз із визначенням коефіцієнта Spearman [1].

Результати дослідження та їх обговорення. Ексудативна форма хронічного запального процесу в ПНП характеризувалася найбільш інтенсивним головним болем $(62,40 \pm 0,92$ бала). Абсолютна більшість цих хворих (27 пацієнтів, 96,43%) скаржилася на утруднення носового дихання, у той час як назальна обструкція при проведенні ендоскопії носової порожнини підтверджена лише в 18 (64,29\%) 3 них (табл. 1).

Більшість хворих на ХПС скаржилася на утруднення носового дихання (20 пацієнтів, $83,33 \%)$ і головний біль, хоча інтенсивність останнього була статистично значимо меншою порівняно з хворими на ХЕС (табл. 1).

Інтенсивність головного болю у хворих на ХГР $(43,31 \pm 1,38)$ виявилася найменшою порівня-

Таблиця 1

Результати клінічного дослідження хворих із ринологічною патологісю

\begin{tabular}{|c|c|c|c|}
\hline Групи хворих & Головний біль & $\begin{array}{c}\text { Суб'єктивне відчуття } \\
\text { утруднення носового ди- } \\
\text { хання } \\
\end{array}$ & $\begin{array}{c}\text { Назальна обструкція, ви- } \\
\text { явлена при ендоскопічно- } \\
\text { му дослідженні } \\
\end{array}$ \\
\hline 1-Хворі на ХГР (n=32) & $\begin{array}{c}43,31 \pm 1,38 ; \sigma=7,81 \\
1-2 *, 1-3 *, 1-4^{*} \\
\end{array}$ & $\begin{array}{c}22(68,75 \%) \\
1-2 * ; 1-3 * \\
\end{array}$ & $\begin{array}{c}32(100 \%) \\
1-2 *, 1-3 *, 1-4 *\end{array}$ \\
\hline 2-Хворі на XEC $(\mathrm{n}=28)$ & $\begin{array}{c}62,40 \pm 0,92 ; \sigma=5,05 \\
2-3^{*}, 2-4^{*} \\
\end{array}$ & $\begin{array}{c}27(96,43 \%) \\
2-4^{*} \\
\end{array}$ & $\begin{array}{c}18(64,29 \%) \\
2-3 *, 2-4 * \\
\end{array}$ \\
\hline 3-Хворі на ХПС (n=24) & $\begin{array}{c}57,08 \pm 1,07 ; \sigma=5,24 \\
3-4 * \\
\end{array}$ & $\begin{array}{c}20(83,33 \%) \\
3-4 * \\
\end{array}$ & $\begin{array}{c}20(83,33 \%) \\
3-4 * \\
\end{array}$ \\
\hline 4-Контроль (n=20) & $39,89 \pm 0,89 ; \sigma=3,79$ & $1(5 \%)$ & $2(10 \%)$ \\
\hline
\end{tabular}

(c) С.А. Левицька, 2016 
Таблиця 2

Результати радіологічного дослідження хворих із синологічною патологією за шкалою Lund-Mackay

\begin{tabular}{|c|c|c|c|c|c|c|}
\hline \multirow{2}{*}{$\begin{array}{c}\text { Групи хво- } \\
\text { рих }\end{array}$} & \multicolumn{4}{|c|}{ Затемнення } & \multirow{2}{*}{ БОК } & \multirow{2}{*}{ Сума } \\
\hline & ВЩ & ПР & $3 \mathrm{P}$ & СФ & & \\
\hline $\begin{array}{l}\text { 1-Хворі на } \\
\text { ХГР (n=32) }\end{array}$ & $\begin{array}{c}13(40,63 \%) \\
1-2^{*}, 1-3^{*}, 1- \\
4^{*}\end{array}$ & $\begin{array}{c}3(9,38 \%) \backslash \\
1-2^{*}, 1-3^{*}\end{array}$ & $\begin{array}{l}3(9,38 \%) \\
1-2^{*}, 1-3^{*}\end{array}$ & $\begin{array}{l}3(9,38 \%) \\
1-2^{*}, 1-3^{*}\end{array}$ & 0 & $\begin{array}{c}0,94 \pm 0,20 \\
\sigma=1,11 \\
1-2 *, 1-3 *\end{array}$ \\
\hline $\begin{array}{c}\text { 2-Хворі на } \\
\text { XЕС }(\mathrm{n}=28)\end{array}$ & $\begin{array}{l}28(100 \%) \\
2-3^{*}, 2-4^{*}\end{array}$ & $\begin{array}{c}20 \\
(71,43 \%) \\
2-4^{*} \\
\end{array}$ & $\begin{array}{c}17(60,71 \%) \\
2-3 *, 2-4^{*}\end{array}$ & $14(50 \%)$ & $16(57,4 \%)$ & $\begin{array}{c}6,40 \pm 0,43 \\
\sigma=2,36 \\
2-4^{*}\end{array}$ \\
\hline $\begin{array}{c}\text { 3-Хворі на } \\
\text { ХПС (n=24) }\end{array}$ & $\begin{array}{c}21(87,5 \%) \\
3-4 *\end{array}$ & $\begin{array}{c}21(87,5 \%) \\
3-4^{*}\end{array}$ & $\begin{array}{c}21(87,5 \%) \\
3-4^{*}\end{array}$ & $16(66,67 \%)$ & $14(58,33 \%)$ & $\begin{array}{c}8,46 \pm 0,62 \\
\sigma=3,02 \\
3-4 *\end{array}$ \\
\hline $\begin{array}{c}\text { 4-Контроль } \\
(\mathrm{n}=20)\end{array}$ & $5(25 \%)$ & $2(10 \%)$ & $2(10 \%)$ & 0 & 0 & $\begin{array}{c}0,56 \pm 0,17 \\
\sigma=0,70\end{array}$ \\
\hline
\end{tabular}

Примітка. БОК - блок остіомеатального комплексу, ВЩ - верхньощелепний синус, ПР - передні решітки, ЗР - задні решітки, СФ - сфеноїдальний синус

Таблиця 3

Кореляція клінічних симптомів ринологічних захворювань із результатами радіологічного дослідження приносових пазух

\begin{tabular}{|c|c|c|c|c|}
\hline \multirow[b]{2}{*}{ Коефіцієнти кореляції Спірмена } & \multicolumn{4}{|c|}{ Групи дослідження } \\
\hline & $\begin{array}{c}\text { Хворі на ХГР } \\
(\mathrm{n}=32)\end{array}$ & $\begin{array}{c}\text { Хворі на XЕС } \\
(\mathrm{n}=28)\end{array}$ & $\begin{array}{c}\text { Хворі на ХПС } \\
(\mathrm{n}=24)\end{array}$ & $\begin{array}{l}\text { Всього } \\
(\mathrm{n}=84)\end{array}$ \\
\hline \multicolumn{5}{|c|}{ Між інтенсивністю головного болю і однією з ознак } \\
\hline загальною сумою за шкалою Lund-Mackay & 0,1 & 0,09 & $-0,15$ & 0,12 \\
\hline Затемненням верхньощелепної пазухи & 0 & $0,32 *$ & $0,32 *$ & 0,19 \\
\hline Затемненням передніх решіток & 0 & $-0,28^{*}$ & $-0,13$ & 0,18 \\
\hline Затемненням задніх решіток & $0,28^{*}$ & $0,29 *$ & 0,17 & 0,18 \\
\hline Затемненням сфеноїдального синуса & $0,38 * *$ & 0,15 & $0,28 *$ & $0,30 *$ \\
\hline \multicolumn{5}{|c|}{ Між відчуттям утруднення носового дихання і однією з ознак } \\
\hline загальною сумою за шкалою Lund-Mackay & $0,3^{*}$ & 0,19 & 0,14 & 0,19 \\
\hline Затемненням верхньощелепного синуса & $-0,27 *$ & $-0,21$ & 0,18 & 0,12 \\
\hline Затемненням передніх решіток & $-0,25$ & $-0,04$ & $0,30^{*}$ & 0,18 \\
\hline Затемненням задніх решіток & 0,15 & 0,02 & $0,40 * *$ & $0,27 *$ \\
\hline Затемненням сфеноїдального синуса & 0,15 & $-0,04$ & $0,32 * *$ & $0,26^{*}$ \\
\hline
\end{tabular}

но з хворими на ХЕС і ХПС, проте статистично значимо перевищувала відповідний показник у групі контролю $(39,89 \pm 0,89)$ (табл. 1).

Цікавим фактом є дані ендоскопії носової порожнини в контрольній групі, згідно 3 котрими в $10 \%$ обстежуваних (2 пацієнти) діагностовано назальну обструкцію, в той час як скарги на утруднення носового дихання висловили лише 5 \% (табл. 1).

Оцінка даних томографії ПНП показала, що хронічним запальним процесом найчастіше уражується верхньощелепна пазуха (у 100 \% хворих на XEC і 87,5 \% хворих на ХПС) (табл. 2). Ураження решітчастого лабіринту виявили в більшості хворих на XC.

У групі контролю 5(25\%) пацієнтів мали інфільтративний вміст верхньощелепних пазух, 2 $(10 \%)$ - клітин решітчастого лабіринту (табл. 2). Така ж частота ураження решітчастих клітин виявлена і в групі хворих на ХГР, у той час як зате- мнення верхньощелепних пазух виявлено в 13 (40,63\%) (табл. 2).

Загальна сума за шкалою Lund-Mackay виявилася найвищою у хворих на ХПС $(8,46 \pm 0,62)$, дещо меншою - у пацієнтів із ексудативною формою хронічного синуситу $(6,40 \pm 0,43)$ (табл. 2$)$.

Дослідження кореляції між інтенсивністю головного болю і результатами рентгенологічного дослідження виявило погану кореляцію між клінічними і рентгенологічними симптомами в більшості випадків. Позитивна кореляція середньої сили між затемненням задніх решіток і сфеноїдального синуса та інтенсивністю головного болю виявлено у хворих на ХГР. Виявлений факт може свідчити про запізнілу діагностику запальних процесів у задній групі ПНП у хворих на ХГР.

У групах хворих на ХЕС і ХПС інтенсивність головного болю корелювала із затемненням верхньощелепної пазухи (табл. 3), встановлений 
кореляційний зв'язок слабкої сили між інтенсивністю головного болю і затемненням решітчастих клітин у хворих на ХЕС; кореляційний зв'язок слабкої сили між інтенсивністю головного болю і затемненням сфеноїдального синуса у хворих на ХПС (табл. 3).

Не виявлено кореляції між загальною сумою балів за шкалою Lund-Mackay та інтенсивності головного болю в жодній групі.

Слабкий кореляційний зв'язок встановлений між відчуттям утруднення носового дихання i загальною оцінкою результатів КТ у хворих на ХГР, відчуттям утруднення носового дихання i затемненням задніх решіток і сфеноїдального синуса у хворих на ХПС (табл. 3 ).

Погана кореляція клінічних і рентгенологічних симптомів у хворих на різноманітну ринологічну патологію робить необхідним обов'язкове включення в алгоритм обстеження хворого із підозрою на ХC як клінічних ендоскопічних, так і рентгенологічних методів обстеження.

\section{Висновки}

1. У групі практично здорових людей за відсутності ринологічної симптоматики затемнення верхньощелепної пазухи на комп'ютерній томографії мав кожен четвертий обстежуваний.

2. Відсутність сильної кореляції між інтенсивністю основних клінічних проявів ексудативного і поліпозного синуситів, хронічного гіпертрофічного риніту і загальними результатами комп'ютерної томографії приносових пазух змушує бути обережними щодо діагностування захворювань верхніх дихальних шляхів виключно на підставі результатів додаткових методів дослідження.

Перспективи подальших досліджень. Встановлення зв'язків результатів клінічних, інструментальних, рентгенологічних, біохімічних, мікробіологічних обстежень хворих на запальні захворювання верхніх дихальних шляхів дозволить вдосконалити алгоритм діагностики і лікування.

\section{Література}

1. Халафян A.A. Statistica 6. Статистический анализ данных. 3-е изд. Учебник / Халафян А.А. - М.: ООО «Бином-Пресс», 2007. - 512 с.,ил.

2. Concha bullosa, nasal septal deviation and paranasal sinusitis; a computed tomographic evaluation / R. Javadrashid, M. Naderpour, S. Asghari [et al.] // B-ENT. 2014. - Vol. 10 (4). - P. 291-298.

3. Endoscopic, radiological, and symptom correlation of olfactory dysfunction in pre- and postsurgical patients of chronic rhinosinusitis / D.Gupta, A.Gulati, I.Singh, U.Tekur // Chem. Senses. - 2014. - Vol. 39 (8). - P. 705-710.

4. Primary care and upfront computed tomography scanning in the diagnosis of chronic rhinosinusitis: a cost-based decision analysis / R.M. Leung, R.K. Chandra, R.C. Kern [et al.] // Laryngoscope. - 2014. -Vol. 124 (1). - P.12-18.

5. Smith S.R. Treatment of mild to moderate sinusitis S.R. Smith, L.G. Montgomery, J.W. Williams Jr. // Arch. Intern. Med. - 2012. - Vol. 26; 172 (6). - P. 510-513.

6. Tiwari R. Study of anatomical variations on $\mathrm{CT}$ in chronic sinusitis / R. Tiwari, R. Goyal // Indian J. Otolaryngol. Head Neck Surg. - 2015. - Vol. 67 (1). - P. 18-20.

7. Validation of the Headache Impact Test (HIT-6) in patients with chronic migraine / R.Rendas-Baum, M.Yang, S.F.Varon [et al.] // Health Qual Life Outcomes. - 2014. Vol. 1, № 12. - P. 117.

\section{КОРРЕЛЯЦИЯ КЛИНИЧЕСКИХ СИМПТОМОВ И РЕЗУЛЬТАТОВ КОМПЬЮТЕРНОЙ ТОМОГРАФИИ ОКОЛОНОСОВЫХ СИНУСОВ У БОЛЬНЫХ РИНОЛОГИЧЕСКОЙ ПАТОЛОГИЕЙ}

\section{С.А. Левицкая}

Резюме. Определена корреляция между интенсивностью клинических симптомов и результатами компъютерной томографии околоносовых синусов у 32 больных хроническим гипертрофическим ринитом, 28 больных хроническим экссудативным синуситом, 24 больных хроническим полипозным синуситом и 20 человек контрольной группы. Затемнение верхнечелюстного синуса выявлено у каждого четвертого обследованного контрольной группы. Не выявлено корреляции между общей суммой баллов по шкале Lund-Mackay и интенсивностью головной боли. Установлена корреляция средней силы между интенсивностью головной боли и затемнением верхнечелюстного синуса у больных экссудативным $(\mathrm{Sp}=0,32)$ и полипозным синуситами $(\mathrm{Sp}=0,32)$.

Ключевые слова: компъютерная томография, синусити, корреляция.

\section{CORRELATION OF CLINICAL SYMPTOMS AND RESULTS OF CT-SCAN OF PARANASAL SINUSES IN PATIENTS WITH RHINOLOGIC PATHOLOGY}

\section{S. A. Levytska}

Abstract. The correlation between the intensity of clinical symptoms and results of CT of paranasal sinuses has been determined in 22 patients with chronic hypertrophic rhinitis, 28 patients with chronic exudative sinusitis and 24 patients with chronic polypus sinusitis and 20 control individuals. The eclipse of maxillary sinus was revealed in one out of four surveyed in the control group. There was no correlation between total scores on the Lund-Mackay scale and intensity of headaches. The correlation between intensity of headaches and eclipse of maxillary sinus was revealed in patients with exudative $(\mathrm{Sp}=0,32)$ and polypus $(\mathrm{Sp}=0,32)$ sinusitis.

Key words: CT-scan, sinusitis, correlation.

Higher State Educational Institution of Ukraine "Bukovinian State Medical University" (Chernivtsi)

Рецензент - доц. С.Ю. Кравчук

Buk. Med. Herald. - 2016. - Vol. 20, № 1 (77). - P. $62-64$ 